\title{
Impact of Income on Customers' Loyalty: Are Customers with Higher Income more Loyal?
}

\author{
Igor Klopotan, Kristina Vrhovec-Žohar
}

University North, Croatia

Edita Mahič

Faculty of Commercial and Business Sciences, Celje, Slovenia

\begin{abstract}
Background: Recent research on customers' loyalty mostly focuses on several indicators, such as price, income and promotion. However, the level of income and its impacts on customers' loyalty have not been investigated in greater details. Objectives: The main goal of this research is to investigate how different levels of income influence customers' loyalty. Methods/Approach: This paper tries to investigate customers' attitudes towards selected loyalty determinants, based on the survey research. Results: Several different factors which influence customers' loyalty are identified. Research results confirmed that the level of income has a significant influence on customers' attitude towards loyalty determinants in Croatia. Conclusions: Besides the scientific contribution, this research on customers' loyalty also has practical implications important when undertaking further steps for developing conceptual models of customers' loyalty.
\end{abstract}

Keywords: marketing; loyalty; economics; customer loyalty management

JEL classification: C10, D31, M31

Paper type: Research article

Received: May 8, 2015

Accepted: Oct 5, 2015

Citation: Klopotan, I., Vrhovec-Žohar, K., Mahič, E. (2016), "Impact of Income on Customers' Loyalty: Are Customers with Higher Income more Loyal?", Business Systems Research, Vol. 7, No. 1, pp. 81-88.

DOI: 10.1515/bsrj-2016-0006

\section{Introduction}

Customer relationship management has a great role in customers' loyalty and satisfaction (Buntak, 2010). However, it is questionable if companies are facing their customers with adequate care. For example, Brdarević i Kulašin (2002) showed that $65 \%$ customers are unsatisfied with offered service. In addition, unsatisfied client share its experience to 11 friends, while satisfied client attract only three new clients. The main focus of former researches is how to retain loyal customers and how to attract the new one. Some of the results will be presented below. 
Loyalty can be defined as dedication to purchase preferred product no matter of situational changes or marketing effort (Oliver, 1999). Mascarenhas et al. (2006) define loyalty trough three dimensions: brand loyalty, behavioral loyalty and situational loyalty. Brand loyalty presents re-buying preferred product constantly in the future. Attitudinal loyalty is connected with a brand, accustomed by positive client attitudes towards specific brand. Behavioral loyalty is presented by revealed buying and usage behavior, accustomed by client satisfaction. However, not all of the customers behave in the same way in every situation. Therefore, situational loyalty depends upon shopping and purchasing situation at one specific moment (Flint, Blocker, Boutin, 2011 ; Uncelsu et al., 2003).

Oliver (1999) in his study claimed that it is important to make difference between loyalty to some specific brand and customers' satisfaction, while satisfaction is just one of many elements of loyalty. On the other side, Akin (2012) consider that loyalty cannot be equal with repeated purchasing, while loyalty depends upon some other factors: (i) brand characteristics, (ii) customers' preferences, (iii) existence of alternative product / services. However, satisfaction and loyalty are tightly aligned while satisfied and loyal customer increase companies success (Khan, 2012).

Oliver (1997) defined a four-stage loyalty model in which loyalty consists of four main factors: belief, affect, intentions, and action. Blut et al (2007) make additional research regarding Oliver's model and expand it with following factors which influence to customers' loyalty: social advantage, attractions of alternatives and price change. Demographic characteristics, such as age, gender and education also play a great role in loyalty. Klopotan et al (2014) confirmed that there is significant statistical difference in customers' loyalty regarding demographic factors. It can be concluded that loyalty cannot be defined through four factors, but that presented model and additional factors, as well as situational change create loyal customer.

There are no much researches which analyze income and its impact to customers' loyalty, especially in post-transition countries. The main goal of the paper is to investigate customers' attitudes towards selected loyalty determinants. In order to achieve the goal, empirical research has been conducted. The questionnaire has been sent to 900 email address in Croatia. The respondents were classified into three groups regarding income level and then compared using Kruskall-Wallis test and post-hoc Mann Whitney test.

The structure of the paper is following. The first section is Introduction. In the second section methodology and data are presented. Results are explained in the third section of the paper. The fourth section concludes the paper.

\section{Methodology}

\section{Data}

Data about customers' attitude towards loyalty determinants are collected through on-line survey, using random sample of individuals older than 18. The survey has been sent to 900 email address using random choice method on data from one marketing agency database. Out of the total of 900 individuals, 479 respondents participated in the research, which forms a response rate of $53,22 \%$. Out of 479 respondents, more than a half belongs to the age group between 25 to 41 years (56\%). Most of the respondents secondary education (39\%) and third of them have University degree (32\%). 


\section{Research instrument}

Investigating and analyzing other research results and scientific knowledge we define conceptual model in order to present customers' attitudes towards loyalty determinants.

Product related factors. In the first group named Product related factors we investigate determinants such as: product quality and service quality (Kaplan, Norton, 2010), price (Khan, 2012), additional products and services (Grbac, Lončarić 2010) and total image of product (Kotler, 2011). Price and quality have very strong influence to customers' loyalty (Anić, Rajh Piri, Rajh, 2010). There are also determinants which influence on relationship with customers: sales staff kindness, fulfillment customers' wishes, understanding present and future customers' needs (Bašić Buzaljko, 201 1; Monji, Ortlepp, 2011).

Brand related and post-sales related factors. Last two groups named Brand and Post-sales related factors consist of following loyalty determinants: effective and efficient service (Bašić Buzaljko, 2011), effectively deal with customer complaints and easy and quick response to customer complaints (Grbac, Lončarić 2010), courtesy in dealing with customer complaints (Kotler, 2006; Kotler and Kellner, 2008) and other additional services as quick pay and installment. In this research we will also investigate some other determinants regarding brand such as: image, expected value, value for money and effective and efficient service.

Table 1

Research instrument description

\begin{tabular}{|c|c|c|c|}
\hline Code & Item & Mean (St.Dev) & $\begin{array}{c}\text { Cronbach's } \\
\text { alpha }\end{array}$ \\
\hline \multicolumn{4}{|c|}{ Product related factors (PROD) } \\
\hline PROD1 & Product quality (Likert 1-5) & $4.52(0.828)$ & \multirow[t]{4}{*}{0.913} \\
\hline PROD2 & Service quality (Likert 1-5) & $4.41(0.814)$ & \\
\hline PROD3 & Product price (Likert 1-5) & $4.32(0.895)$ & \\
\hline PROD4 & Sales staff kindness (Likert 1-5) & $4.27(0.827)$ & \\
\hline \multicolumn{4}{|c|}{ Brand related factors (BRAND) } \\
\hline BRAND1 & Image (Likert 1-5) & $3.79(0.980)$ & \multirow[t]{5}{*}{0.825} \\
\hline BRAND2 & Expected value (Likert 1-5) & $4.09(0.913)$ & \\
\hline BRAND3 & Value for money (Likert 1-5) & $4.11(0.958)$ & \\
\hline BRAND4 & Effective and efficient service (Likert 1-5) & $4.23(0.832)$ & \\
\hline BRAND5 & Quick pay and installment (Likert 1-5) & $4.02(0.930)$ & \\
\hline \multicolumn{4}{|c|}{ Post-sales related factors (POST) } \\
\hline POSTI & Easy and quick response to customer complaints & $4.19(0.907)$ & \multirow[t]{3}{*}{0.725} \\
\hline POST2 & Effectively deal with customer complaints & $4.18(0.864)$ & \\
\hline POST3 & Courtesy in dealing with customer complaints & $4.16(0.943)$ & \\
\hline
\end{tabular}

Note: Mean values of the importance estimate of the item (1- Totally unimportant, 5-Very important), standard deviations in parenthesis

Research instrument consists of three groups of loyalty determinants. Through Likert scale ( 1 =completely irelevant; $5=$ completely relevant) respondents evaluate each determinant. In Table 1 selected and most important loyalty determinants are presented. Among all 12 determinants the highest average value has determinant Product quality $(4,52)$, while the lowest average value has determinant Image $(3,79)$. In the first group named Product related factors the highest average value has determinant Product quality $(4,52)$, while the lowest average value is for determinant Sales staff kindness $(4,27)$. In the second group named Brand related factors the highest average value has determinant Effective and efficient service $(4,23)$, while the lowest average value is for determinant Image $(3,79)$. In the third group named 
Post-sales related factors the average values for all three determinants are very similar: Easy and quick response to customer complaints $(4,19)$, Effectively deal with customer complaints $(4,187)$ and Courtesy in dealing with customer complaints $(4,16)$.

In the first research phase, Cronbach alfa coefficients were conducted in order to test reliability of customers' attitude towards different loyalty determinants. The results of Cronbach alfa test are: (i) Product related factor (PROD) - Cronbach alpha 0,913; (ii) Brand related factors (BRAND) - Cronbach alpha 0,825; (iii) Post-sales related factors (POST) - Cronbach alpha 0,725. Cronbach alpha is quite high (higher than $0,7)$ for all three groups of loyalty determinants which justify usage of selected determinants.

\section{Statistical methods}

The starting point of the research is that customers' loyalty depends upon income level. In other words, for different group of customers there are different determinants which influence on their loyalty.

In order to group respondents into different groups regarding level of income we used data for 2012. Average income in Croatia in 2012 for active working people was 7.875,00 kuna (DZS, 2012). The minimum income for 2012 was 2.814,00 kuna. Difference between the minimum income and average income in Croatia in 2012 was divided into two equal parts $(7.875,00-2.814,00=5.061,00 / 2=2.530,50)$. In the first group are respondents with above-average income and they earn more than $10.405,50$ kuna monthly $(7.875,00+2.530,50=10.405,50)$. In the third group are respondents with under-average income and they earn less than 5.344,50 kuna $(7.875,00+2.530,50=5.344,50)$. Respondents with average income are those in the second group and they earn between 5.344,50 and 10.405,50 kuna a month. In our calculation we used gross income while net income can be calculated only approximately because of different taxes in different counties in Croatia.

In Table 2 structure of the respondents is presented. More than half respondents have average income (53\%) and only $11 \%$ of respondents have above average income. Third of respondents (36\%) has under-average income.

Table 2

Structure of respondents regarding level of income

\begin{tabular}{lll}
\hline Level of income & Salary range & Structure in \% \\
\hline Under-average & $<5.345,00$ & $36 \%$ \\
Average & $5.345,00-10.405,50$ kuna & $53 \%$ \\
Above-average & $>10.405,50$ & $11 \%$ \\
Total & & $100 \%$ \\
\hline
\end{tabular}

Source: Authors calculation based on DZS data (DZS, 2012)

We used two stage approaches to analyze attitudes towards customers' loyalty according to the income level. First, customers' attitudes towards loyalty determinants were compared according to their income level, using Kruskall-Wallis test for different groups. Second, post-hoc Mann-Whitney test was conducted for different groups of income level.

\section{Results}

Table 3 show average values of customers' attitudes towards loyalty determinants. We have compared all respondents' groups (under-average income, average income and above-average income) and got following results. The highest average value is for Product related factors (Product quality, Service quality and Product price). The lowest average value is for Brand related factors (Image, Quick pay and 
installment and Expected value). The highest difference among average values of loyalty determinants is for the determinant Product price which has the second highest average value in under-average income group. However, for those respondents with above-average income, Product price is not important loyalty determinant.

Table 3

Customers' attitudes towards main loyalty determinants

\begin{tabular}{|c|c|c|c|}
\hline Code & Under-average income & Average income & Above-average income \\
\hline \multicolumn{4}{|c|}{ Product related factors (PROD) } \\
\hline PROD1 & $4.50(0.902)$ & $4.55(0.756)$ & $4.39(0.918)$ \\
\hline PROD2 & 4.39 (0.901) & 4.45 (0.719) & 4.29 (0.944) \\
\hline PROD3 & $4.40(0.842)$ & $4.34(0.894)$ & $3.98(1.010)$ \\
\hline PROD4 & $4.25(0.832)$ & $4.34(0.796)$ & $4.00(0.917)$ \\
\hline \multicolumn{4}{|c|}{ Brand related factors (BRAND) } \\
\hline BRAND1 & $3.86(0.945)$ & $3.76(0.981)$ & $3.75(1.093)$ \\
\hline BRAND2 & $4.09(0.880)$ & $4.10(0.910)$ & $4.06(1.047)$ \\
\hline BRAND3 & $4.17(0.892)$ & $4.12(0.962)$ & $3.89(1.090)$ \\
\hline BRAND4 & $4.23(0.842)$ & $4.26(0.807)$ & $4.02(0.905)$ \\
\hline BRAND5 & $4.04(0.920)$ & $4.09(0.892)$ & $3.61(1.060)$ \\
\hline \multicolumn{4}{|c|}{ Post-sales related factors (POST) } \\
\hline POSTI & $4.10(0.947)$ & $4.25(0.875)$ & $4.14(0.917)$ \\
\hline POST2 & $4.10(0.859)$ & $4.24(0.860)$ & $4.14(0.895)$ \\
\hline POST3 & $4.09(0.960)$ & $4.21(0.936)$ & $4.18(0.919)$ \\
\hline
\end{tabular}

Note: Mean values of the importance estimate of the item (1- Totally unimportant, 5-Very important), standard deviations in parenthesis

When the Kruskal-Wallis test leads to statistically significant results, then at least one of the samples is different from the other samples. In Table 4 data about different groups of respondents are presented and the results show that there is statistically significant difference in customers' attitudes towards loyalty determinants in $1 \%$ for the determinants BRAND5 Quick pay and installment ( $p$-value $=0.008$ ) and in $5 \%$ for the determinants PROD3 Product price ( $p$-value $=0.016$ ) and PROD4 Sales staff kindness ( $p$-value $=0.033$ ).

Table 4

Kruskall-Wallis test for different groups

\begin{tabular}{cccc}
\hline Code & \multicolumn{1}{c}{ Chi-Square } & df & Asymp. Sig. \\
\hline & \multicolumn{4}{c}{ Product related factors (PROD) } \\
\hline BR1 & 1.161 & 2 & 0.560 \\
BR2 & 0.483 & 2 & 0.786 \\
BR3 & 8.312 & 2 & $0.016^{* *}$ \\
BR4 & 6.850 & 2 & $0.033^{* *}$ \\
\hline \multicolumn{5}{c}{ Brand related factors (BRAND) } \\
\hline GP1 & 0.075 & 2 & 0.963 \\
GP2 & 1.650 & 2 & 0.438 \\
GP3 & 3.395 & 2 & 0.183 \\
GP4 & 9.590 & 2 & $0.008^{* * *}$ \\
GP5 & 1.242 & 0.537 \\
\hline AS1 & 2 & 0.219 \\
\hline AS2 & Post-sales related factors (POST) & 0.216 \\
AS3 & 3.039 & 2 & 0.356 \\
\hline
\end{tabular}

Note: ${ }^{* * *}$ statistically significant at $1 \%,{ }^{* *}$ statistically significant at $5 \%,{ }^{*}$ statistically significant at $10 \%$ 
Post-hoc Mann-Whitney test was conducted in order to determine is there statistically significant difference among respondents groups regarding income level (Table 5). Results and the level of reliability among groups are presented in Table 5. Statistical significant difference exists for the following determinants: (i) product price,

(ii) sales staff kindness and (iii) quick payment and installment:

- Product price: statistical significant difference among respondents with underaverage above-average income

- Product price: statistical significant difference among respondents with average and above-average income

- Sales staff kindness: statistical significant difference among respondents with average and above-average income

- Quick pay and installment: statistical significant difference among respondents with under-average and above-average income

- Quick pay and installment: statistical significant difference among respondents with average and above-average income

Table 5

Post-hoc Mann-Whitney test for different groups (statistically significant differences)

\begin{tabular}{|c|c|c|c|}
\hline Groups & & Mann-Whitney U & Asymp. Sig. (2-tailed) \\
\hline \multicolumn{4}{|c|}{ BR3 - Product price (Likert 1-5) } \\
\hline Under-average & Above-average & 3.357 & $0.005^{* * *}$ \\
\hline Average & Above-average & $5.169,50$ & $0.011^{* *}$ \\
\hline \multicolumn{4}{|c|}{ BR4 - Sales staff kindness (Likert 1-5) } \\
\hline Average & Above-average & $5.138,50$ & $0.010^{* *}$ \\
\hline \multicolumn{4}{|c|}{ GP4- Quick pay and installment (Likert 1-5) } \\
\hline Under-average & Above-average & $3.340,50$ & $0.007^{* * *}$ \\
\hline Average & Above-average & $4.837,50$ & $0.002^{* * *}$ \\
\hline
\end{tabular}

Note: ${ }^{* * *}$ statistically significant at $1 \%,{ }^{* *}$ statistically significant at $5 \%,{ }^{*}$ statistically significant at $10 \%$

\section{Conclusion}

Results showed that the highest average values have determinants product and service quality and product price from the first group named Product related factors. The lowest average values have determinants image, expected value and value for money from the second group named Brand related factors.

There is also difference between respondents with under-average versus aboveaverage income. Respondents with under-average income consider price as very important loyalty determinant, while those respondents with average and aboveaverage income consider product quality as important loyalty determinant.

Research results confirmed that level of income has significant influence to customers' attitude towards loyalty determinants in Croatia. There is significant statistical difference for following determinants: (i) product price, (ii) sales staff kindness and (iii) quick pay and installment. It can be concluded that statistical significant difference is confirmed for determinants regarding product and brand factors and it is not confirmed for determinants regarding post-sales factors.

The factors that have the significant impact to the customers' loyalty are following:

- Product price: The paper demonstrated that for those with low income, price plays the most important role in loyalty determinants. Individuals who earn more do not pay attention to price, but to quality and post-sale satisfaction. 
- Sales staff kindness: The research found out that respondents with high income pay more service than product they buy. The price is not important for them and they are more focused on performance of sales staff while providing a complete sale service.

- Quick pay and installment: The research found out that for both group of respondents, those with low or high income, quick pay and installment has a great impact to loyalty. Companies has to pay more attention to this factor while money and all actions about it, like paying, is very delicate issue for all individuals.

This research is about customers' attitude towards loyalty determinants in Croatia. The limits of the research are geographically limitation to Croatia region and rather small sample of respondents. According to national and cultural conditions research is limited to specific customer behavior in Croatia. The empirical analysis presented in this paper should be extended by future qualitative and quantitative research, in order to get a broaden understanding of the factors defining the customers' attitude regarding loyalty determinants.

The main goal for all sales oriented companies is profit through customer satisfaction. Today, clients have access to more information and to a greater choice and companies are struggling to retain and to attract new customers. Improving relationships with customers, satisfying their needs and accomplishing their wishes, companies increase their competitiveness on the market and create loyal customers. Beside scientific contribution this research about customers' loyalty has also practical implication in proposing further steps for developing conceptual model of customer's loyalty.

\section{References}

1. Akın, E. (2012). Literature Review and Discussion on Customer Loyalty and Consciousness, European Journal of Economics, Finance and Administrative Sciences, Vol. 51, pp.158-173.

2. Anić, I.D., Rajh Piri, S., Rajh E. (2010). Utjecaj kvalitete i cijene na lojalnost marki, Ekonomski pregled, Vol. 61, No. 3-4, pp. 137-150.

3. Bašić Buzaljko, M. (2011). Teoretsko istraživanje razvoja sistema kvaliteta Studentskog centra Zenica. Neum. 7. naučno stručni skup sa međunarodnim učešćem, Kvalitet 2011.

4. Blut, M., Evanschitzky, H., Vogel, V., Ahlert, D. (2007). Switching Barriers in the FourStage Loyalty Model, Advances in Consumer Research, Vol. 34, pp. 726-734.

5. Brdarević S., Kulašin Dž. (2002). Metode mjerenja zadovoljstva kupca prema ISO 9001:2000, Mašinstvo, Vol. 4, No. 6, pp. 251-264.

6. Buntak, K. (2010). Model definiranja i upravljanja ključnim parametrima intelektualnog kapitala $u$ organizaciji. Sarajevo. Ekonomski fakultet u Sarajevu. Doktorska disertacija.

7. Flint, D. J., Blocker, C. P., \& Boutin Jr, P. J. (2011). Customer value anticipation, customer satisfaction and loyalty: An empirical examination, Industrial Marketing Management, Vol. 40, No. 2, pp. 219-230.

8. Grbac, B., Lončarić, D. (2010). Ponašanje potrošača na tržištu krajnje i poslovne potrošnje. Rijeka. Ekonomski fakultet Sveučilišta U Rijeci. ISBN: 978-953-6147-90-5.

9. Hrvatski državni zavod za statistiku. (2012). Mjesečno statističko izvješće 2012. http://www.dzs.hr/. Accessed 25 April 2014.

10. Kaplan, R. S., Norton D. P. (2010). Uravnotežena tablica rezultata. Zagreb. Mate d.o.o. CIP zapis Nacionalne i sveučilišne knjižnice u Zagrebu pod brojem 729705.

11. Khan, O. (2012). Towards understanding customer loyalty: An empirical study on emotional attachment, International Journal of Innovations in Business, Vol. 1, No.

3, pp. 241-267. 
12. Klopotan, I., Buntak, K., Drožđek, I. (2014). Impact of Education, Gender and Age on Consumer Loyalty. International Journal for Quality Research, Vol. 8, No. 4, pp. 481-494.

13. Kotler, P. (2006). Osnove marketnga. Zagreb, MATE.

14. Kotler, P. (2011). Reinventing marketing to manage the environmental imperative, Journal of Marketing, Vol. 75, No. 4, pp. 132-135.

15. Kotler, P., Kellner, K. (2008). Upravljanje marketingom, Zagreb. MATE. ISBN: 0-13145757-8.

16. Mascarenhas, O.A., Kesavan, R., Bvernacchi, M. (2006). Lasting Customer Loyalty: A Total Customer Experience Approach, Journal of Consumer Marketing, Vol. 23, No. 7, pp. 397-405.

17. Monji, L., Ortlepp, K. (2011). The Relationship between Organisational Trust, Job Satisfaction and Intention to Leave: An Exploratory Study. Management, Informatics and Research Design, 192.

18. Oliver, R. L. (1997). Satisfaction: A Behavioral Perspective on the Consumer, McGraw Hill, NY

19. Oliver, R. L. (1999). Whence Consumer Loyalty?, Journal of Marketing, Vol. 63, pp. 33-44.

20. Uncles, M. D., Dowling, G. D., Hammond, K. (2003). Customer Loyalty and Customer Loyalty Programs, Journal of Consumer Marketing, Vol. 20, No. 4, pp. 294-317.

\section{About the authors}

Igor Klopotan, Master of Economics, is a lecturer at the University North, Department of Business and Management, and a PhD candidate at the Faculty of commercial and business science in Slovenia. He is the author and co-author of numerous domestic and international professional and scientific articles, and has participated in several international conferences. He is a member of the program committee of the international scientific conference Entrenova 2016. Author can be contacted at igor.klopotan@unin.hr

Kristina Vrhovec - Žohar, Master of Economics, is the director of a Business center Križevci Ltd. in Križevci, and a teaching assistant at the University North, in Koprivnica, the Department of Business and Management. She is the author and co-author of several national and international scientific and professional papers. Since 2005, she worked as the organizer and active participant in a series of workshops and round tables, particularly related to the development of entrepreneurship programs and projects of the EU, and international conferences. She currently works on several projects related to the development of entrepreneurship and local government. Author can be contacted at kvrhovec@unin.hr

Edita Mahić, Master of Economics, is director of a private company, and president of the Slovenian Chamber of Commerce, the section for medical devices, and PhD candidate at the Faculty of commercial and business science in Slovenia. She is the author and co-author of many national and international scientific papers. She has held several guest lectures at foreign universities. Author can be contacted at edita.mahic@gmail.com 